\title{
Delays in Construction Projects: Causes and Mitigation
}

Aleksander Srdić, Ph.D. University of Ljubljana, Faculty of

Civil and Geodetic Engineering, Slovenia

aleksander.srdic@fgg.uni-lj.si
Assoc. Prof. Jana Šelih, Ph.D.

University of Ljubljana, Faculty of

Civil and Geodetic Engineering,

Slovenia

jana.selih@fgg.uni-lj.si
DOI 10.5592/otmcj.2015.3.5

Research paper
DURING EXECUTION OF CONSTRUCTION PROJECTS, THE WORKS PROCEED AT A SLOWER PACE THAN PLANNED, AND DELAYS FREQUENTLY APPEAR. THEIR APPEARANCE LEADS TO ADDITIONAL COST GENERATION, CONFLICTS AMONG PROJECT PARTICIPANTS AND, IN WORST-CASE SCENARIO, LITIGATION. The presented study uses online survey as the research tool in order to determine the current level of use of time management techniques and tools in Slovenian construction industry. The obtained results show that the construction companies could use the available contemporary time management tools in larger extent, as well as more efficiently in order to manage their projects more efficiently.

\section{Keywords}

Delays; Construction

Project; Responsibility; Empirical study 


\section{INTRODUCTION}

Construction projects are complex endeavours, associated with large costs and long duration. A large number of interconnected activities carried out by different project participants need to be carried out during execution of a construction project. Even when the plans are prepared with due diligence, uncertainties and unexpected events appear during project execution. Often, such events lead to delays that have an adverse effect upon the execution and performance of the project [1-3], all construction project stakeholders (including final users) may suffer when a delay occurs [4].

Delays occur due to a variety of reasons (or, in other words, have various origins); con be compensated or not; and they may appear concurrently or subsequently. Further, the impact caused on the project performance may be direct or indirect. Their appearance leads to additional cost generation, conflicts among project participants and, in worst-case scenario, litigation where additional costs may be generated.

Often, delays appear already in the initial stages of the construction projects, such as the stage of the preparation of the general plans, or conceptual design, obtaining the building permit etc. As a consequence, the construction process itself is frequently delayed already at its start, due to the occurrence of delays in previous phases. Special attention should be therefore placed to the preparation stage, and ensure that adequately detailed documentation is available at the start of the project.

When dealing with the delays, it is not only important to identify delays and quantify the delay impacts on project performance but also to identify and quantify the impacts of delays already occurred upon further project development. In order to determine responsibility and enable to learning from these undesirable events, the primary causes and origin of delays should be identified as well.

The responsibility for the occurrence of a particular delay can be allocated to one (or several) project stakeholders. If these responsibilities are not identified before the onset of the project, there is a risk of conflicts among project stakeholders regarding the responsibility allocation that may lead even to litigation. Responsibility allocation matrix defined prior to the project can therefore be an extremely useful conflict management tool as it clarifies the roles and responsibilities in projects. On this basis, the financial compensation for harmful events can be determined.

\section{Literature survey}

Delays have been systematically analyzed by several researchers. Sweis et al [5] used, as the baseline, the com- parison between the as-planned and as-built schedule, since this information form the basis for resolving claims and disputes among the stakeholders involved. Yang \& Kao [6] reviewed 18 delay analysis methods. On this basis, they proposed 6 suggestions to be used in development an ideal delay method. Application of window analysis, where the critical path is split into timeframes, and only partial as-built critical paths are modelled, was presented in this work as well.

in their work, Sun \& Meng [7] conducted a comprehensive survey of literature. The obtained results show that the identification of delays is predominantly carried out on the basis of existing documentation of the completed projects; more precisely, this method was used in 49 papers out of 101 surveyed articles. In 36 papers, the delays were studied by obtaining the response through the use of standardized questionnaires that included questions of ranking the importance of individual causes. Case study approach and interviews were used in 28 and 13 articles, respectively. The classification of delays that can be found in the relevant professional and scientific literature is most often based on identification of the delay origin, or, in other words, responsibility for the delay.

Kartam [8] classified the delays with respect to their timing, compensability and impact, as presented in Figure 1.

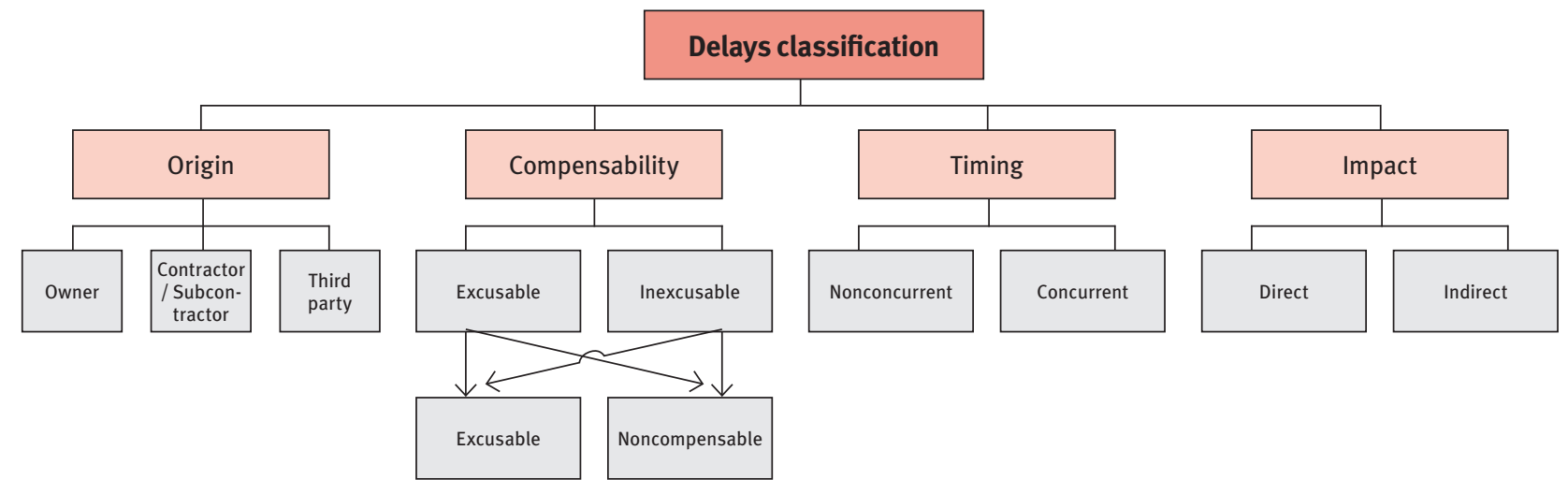

Figure 1: Classification of delays. [8] 
A delay is compensable to the contractor when it is caused by the owner, e.g. incomplete drawing and specification, changes in scope or late possession of site. The conditions of contract should allow the contractor to be entitled to a time extension and to monetary recompense for extra costs caused by the delay. Excusable delays are occurrences over which neither the owner nor the contractor have any control, e.g. extreme weather conditions, acts of God and other unforeseen future events. In this case, the contractor should declare an excusable delay and can thus be entitled to time extension. Non-excusable delays caused by the general contractor lead to the position where the contractor is entitled neither to time extension nor to monetary recompense from the owner. In addition, the contractor may pay liquidated damages according to the contract.

Empirical evidence was analysed as well; for example, Sweis \& al [5] have found, by conducting an empirical study among construction project stakeholders in Jordan, that change orders by the client and financial difficulties of the contractor are the leading causes of construction delays. Research where 79 legal cases in Taiwan (that relate to schedule delays in construction projects) were analysed was carried out by Yang \& al [9]. He found that the main causes of schedule delays were changes orders, changed scope of work, delayed site handover and weather.

Recent research in the area of delays in construction include the work of Mahamid et al [10] and Pourrostam \& Ismail [11], where the delays were studied from the consultants' perspective. The authors identify bid award for the lowest price, changes in specifications and materials types during construction as top delay causes. Furthermore, Gonzales \& al [1] analyzed the causes of delay and time performance in construction projects on the basis of 2 indicators, by which both the causes and their impact upon time performance of the project can be described.

\section{Research goals and methodology}

The aim of the research presented in this paper is first to establish, on the basis of literature survey, classification of delays. The second research goal is to determine the attitudes of different construction project stakeholders regarding the occurrence, type and allocation of responsibility for the delays in Slovenia. An on-line survey among the stakeholders was used as the research tool. In order to formulate the content of the questionnaire used in the survey, an extensive literature survey was carried out by which the key problems of time management during execution of construction projects were identified.

\section{Fundamentals of Delay Analysis}

Determination of delay causes has to be based on objective delay analysis; therefore, analysing construction delays has become an integral part of a project's construction life. Even with today's technology and understanding of project management techniques, construction projects continue to suffer delays, and project completion dates still get pushed back. A number of solution methods and delay analysis techniques were developed and their usefulness and selection of proper method are based on available project date and its quality.

The most comprehensive taxonomy and classification is presented in Recommended practice published by the Association AACE International [12]. Schematically, it is presented in Fig. 2.

Regardless of the selected method, the delay analysis procedure should be carried out as a sequence of the following activities [13]:

$\checkmark$ data gathering and collection relevant information,

$\checkmark$ data analysis, where use of different schedules (as planned, as built, immediate schedules) can be employed,

> identification of root causes,

> classification of the delays and their impact, and

> assigning responsibility and determination of compensation.

\subsection{Classification of delay causes}

Within research presented in this paper, the framework of the classification of delay causes was adopted from the pioneer work of [14].

Three categories of the delay causes were identified as relevant in Slovenian construction practice, and as such, they were added to the list of delays. The first category relates to complicated and lengthy procedure of obtaining the building permit. National spatial planning legislature demands that the spatial plans identify, for each plot, special regimes such as cultural or biodiversity preservation. Relevant institutions provide conditions that need to be respected during construction and use of the structure. Al illustrative example is construction of the new ski jump facility in Planica valley that is located in protected area. In order to ensure uninterrupted nesting of the local (protected) birds, the building permit specifically stated that the contractor was not allowed to execute works during their nesting period. As a consequence, the works were interrupted during the nesting period, and deviations from original schedule occurred. Sometimes, additional stakeholders are identified, after submitting the permit request, e.g. renovation of an old building where elements that have cultural heritage value are found only after the onset of works. This category can be labelled »legal issues".

The second cause of delays that became extremely important with the onset of the economic crisis is the financial structure of the project, especially when there is a long chain of subcontractors. Slovenian legislature demands that the payment of works 


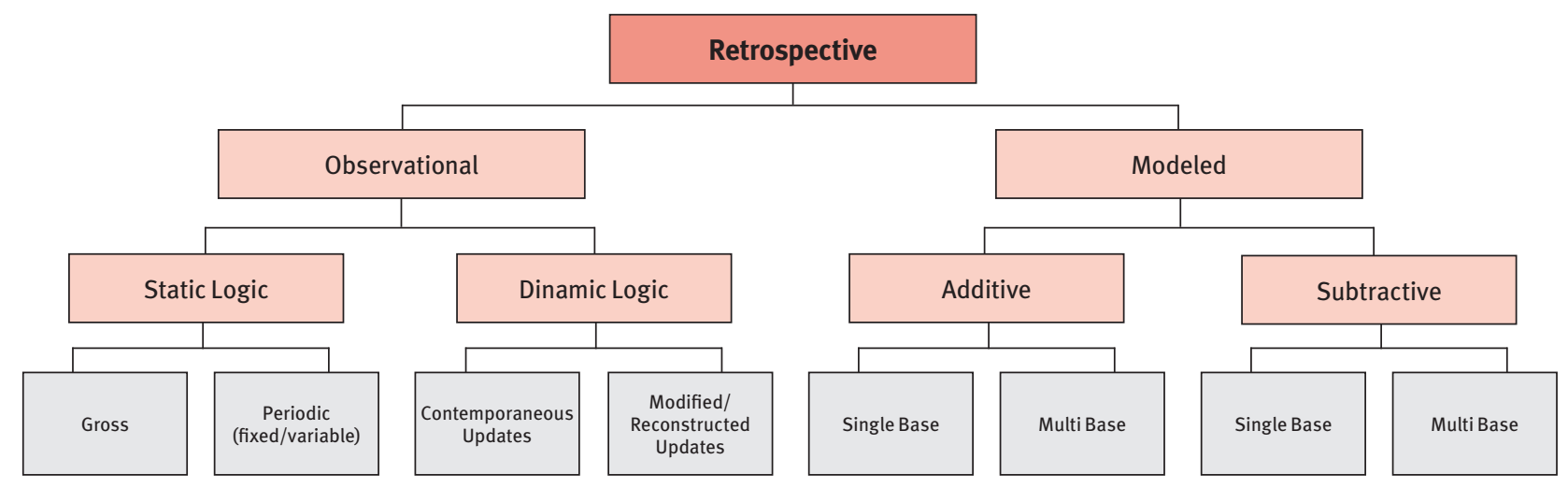

Figure 2: Taxonomy of Retrospective Schedule Analysis. [12]

is carried out after the works are completed, with due date specified in the construction contract. This means that the subcontractors are often paid even later than the contractor, which, in some cases, may lead to the insolvency or even to bankruptcy of the subcontractor who is not able to continue the works due to his financial problems. As a consequence, a delay appears.

The third additionally identified de-

\begin{tabular}{|l|l|}
\hline & Cause \\
\hline 1 & Project causes \\
\hline 2 & Client \\
\hline 3 & $\begin{array}{l}\text { Incomplete design } \\
\text { documentation }\end{array}$ \\
\hline 4 & Execution of works \\
\hline 5 & Material \\
\hline 6 & Rework \\
\hline 7 & Equipment and tools \\
\hline 8 & Acts of God (Force Majeure) \\
\hline 9 & Legal issues \\
\hline 10 & Project financing \\
\hline 11 & Auxiliary project participants \\
\hline
\end{tabular}

Table 1: Causes of delays appearing in construction projects lay cause is related to the project participants who are contractually bound to the general contractor or to the client, such as the Engineer (who is, on one hand, the representative of the client, and on the other hand, required by the legislature), or the subcontractors; in other words, there is no contractual relation between project participant and the client. They are labelled as "Auxilliary project participants").

The resulting list of delay causes in presented in Table 1. We assume that not all listed causes of delay are perceived as equally important.

\section{Survey execution}

The content of the questionnaire to be used in the survey was divided into several sections. In the first part, general data, such as the role of the company answering the survey in the construction process, type and extent of experience, number of performed projects within the last year, and professional background and experience of the respondent were collected.

In the second part, the questions were focused to the construction activities carried out in the responding company. In particular, we assume that the type of the facility to be constructed, i.e. buildings vs engineering works, has an influence upon the occurrence, extent and causes of delay. We also wanted to obtain information regarding the level of use of schedul- ing methods and associated software within project planning and monitoring

The core part of the survey is focused to the delay analysis. The classification used in the survey was adopted as proposed by [14]. Frequency of the following causes of delays was investigated:

general causes (e.g. slow process of relevant spatial act acceptance; administrative causes; land ownership consolidation; acquirement of relevant consents, e.g. from the neighbours, or various other stakeholders);

project financing (delayed payments, financing difficulties);

poor project management (e.g. inadequate communication among project participants, poor scheduling, project manager is appointed too late etc.)

> client (e.g. orders changes after the project is initiated; making decisions too late; conflicts among co-owners);

various causes taking place during execution of works (e.g. poor management of the contractor, inadequate operational planning, poor management of conflicts with subcontractors, executed works are not compliant to the project documentation, ...);

inadequate Engineering (late checks and approvals of the executed works, conflicts between Engineer and the contractor, rigidity of the Engineer, ...); project documentation (e.g. 
incompatibility of drawings, lack of details, poor drawings, late incorporation of changes that were executed, into the drawings; late incorporation of changes into the project documents etc.;

$\checkmark$ construction products (e.g. lack of certain materials and products on the market, damaged materials, late supply of construction products, ...);

$\checkmark$ construction machinery and equipment (e.g. lack of machinery and equipment on contractor's side; non-skilled operators, unavailability of up-to-date machinery etc)

workforce (poorly skilled workers, low productivity, conflicts among foremen and workers, injuries, ...);

> Force Majeure (e.g. different ground conditions as anticipated, unfavourable weather, fire, strikes ....).

An on-line survey containing the questions described above was prepared. The target group of respondents consisted of professionals, either representatives of clients, or contractors. The survey was sent to the representatives of different stakeholders in construction process who were asked to answer the questions. In order to obtain more answers, these respondents we asked to forward the survey to competent individuals who also participated in the construction projects ("rolling snowball principle").

\section{Results}

62 responses were obtained; however, it should be noted that some of them were only partially completed.

The majority of respondents were representatives of clients $(14,5 \%)$, contractors $(22,6 \%)$ and professional engineers (project managers, design engineers and surveying engineers) $(35,5 \%)$. Overall, the results show that they are well experienced, as the reported work experience of $47 \%$ respondents ranges from 5 to 15 years, while the work experience of $32 \%$ respondents ranges from 15 to 25 years. All respondents have completed secondary

\begin{tabular}{|l|r|r|}
\hline & No. of resp. & No. of resp. (\%) \\
\hline Engineers & 44 & 71,0 \\
\hline Architects & 10 & 16,1 \\
\hline Economists & 6 & 9,7 \\
\hline Others & 2 & 3.2 \\
\hline Total & 62 & 100,0 \\
\hline
\end{tabular}

Table 2: Professional background of the respondents.

\begin{tabular}{|l|r|r|}
\hline & No. of resp. & No. of resp. (\%) \\
\hline No scheduling is used & 16 & 25,8 \\
\hline MS Project, Primavera & 25 & 40,3 \\
\hline MS Excel, Word & 18 & 29,0 \\
\hline Other & 3 & 4,8 \\
\hline Total & 62 & 100,0 \\
\hline
\end{tabular}

Table 3: Scheduling tools used by the respondents.

education, and the majority (61,3\%) has the B.Sc. degree. Their educational background varies, but the majority of the respondents are Civil Engineering professionals (Table 2 ).

We assume that companies that use contemporary tools for project scheduling are more efficient in time management; therefore, one question addressed the issue of schedule preparation and monitoring. The answers regarding the scheduling tools' use show that approximately a quarter of respondents do not use scheduling tools at all. Standard software packages for time management, MS Project and Primavera, are used by approximately $40 \%$ of the respondents (Table 3). It is clear that the use of integrated software packages that enable simultaneous time, scope and cost control are not yet a part of daily routine of Slovenian construction industry.

The core part of the survey was focused to the issues related to monitor- ing of works that have been executed against the schedule. The results are presented in Table 4. Weekly monitoring of works is most often ( $43,5 \%)$ encountered; however it is alarming that $7(11,3 \%)$ respondents claim that they don't monitor the progress of actual works at all.

Next important issue is the identification of the actual causes of delay. The types of delay causes were formulated in accordance with the classification of delays presented in Section 2. Three possible answers indicating the frequency of delay occurrence (always; often; never) were offered to the respondents. The results are presented in Table 5 .

It can be seen that legal obstacles (building permit issues etc.), lack of design details and specifications, slow decision making process on the side of the owner and design documentation delays; and change orders form the client's side are perceived as the lead causes of delays. 


\begin{tabular}{|l|r|r|}
\hline $\begin{array}{l}\text { How often do you monitor the } \\
\text { executed works against the } \\
\text { schedule? }\end{array}$ & No. of resp. & No. of resp. (\%) \\
\hline $\begin{array}{l}\text { We do not monitor the execution of } \\
\text { works in terms of time }\end{array}$ & 7 & 11,3 \\
\hline Daily & 9 & 14,5 \\
\hline Weekly & 27 & 43,5 \\
\hline Monthly & 17 & 27,4 \\
\hline Bi-annualy & 2 & 3,2 \\
\hline Total & 62 & 100,0 \\
\hline
\end{tabular}

Table 4: Frequency of executed works' monitoring.

\begin{tabular}{|c|c|c|c|c|}
\hline & Cause of delay & Always & Always \& often & Category of delay \\
\hline 1 & $\begin{array}{l}\text { Legal obstacles with } \\
\text { building permit issues }\end{array}$ & $9,7 \%$ & $53,2 \%$ & Legal \\
\hline 2 & $\begin{array}{l}\text { Lack of design details } \\
\text { and specifications }\end{array}$ & $14,5 \%$ & $50,0 \%$ & Design \\
\hline 3 & $\begin{array}{l}\text { Slow decision making } \\
\text { process issued by owner }\end{array}$ & $6,5 \%$ & $46,8 \%$ & Owner \\
\hline 4 & $\begin{array}{l}\text { Design documentation } \\
\text { delays }\end{array}$ & $8,1 \%$ & $45,2 \%$ & Design \\
\hline 5 & $\begin{array}{l}\text { Change orders and ad- } \\
\text { ditional request issued } \\
\text { by owner }\end{array}$ & $4,8 \%$ & $45,1 \%$ & Owner \\
\hline 6 & $\begin{array}{l}\text { Design documentation } \\
\text { error and discrepancy }\end{array}$ & $6,5 \%$ & $43,6 \%$ & Design \\
\hline 7 & $\begin{array}{l}\text { Inappropriate design } \\
\text { solution }\end{array}$ & $3,2 \%$ & $35,5 \%$ & Design \\
\hline 8 & $\begin{array}{l}\text { Lack of information } \\
\text { gathered before design } \\
\text { stage }\end{array}$ & $3,2 \%$ & $35,5 \%$ & Design \\
\hline 9 & $\begin{array}{l}\text { Delay with spatial plan- } \\
\text { ning documentation }\end{array}$ & $8,1 \%$ & $32,3 \%$ & Legal \\
\hline 10 & Unqualified workforce & $6,5 \%$ & $30,7 \%$ & Client \\
\hline 11 & No project risk analysis & $4,8 \%$ & $30,6 \%$ & Management \\
\hline 12 & $\begin{array}{l}\text { Inappropriate project } \\
\text { management }\end{array}$ & $3,2 \%$ & $30,6 \%$ & Management \\
\hline
\end{tabular}

Table 4: Causes of delays as perceived by the respondents.
The results presented in Table 5 show that the causes of the majority of delays can be attributed to the legal issues, slow decisions of the owner or his representative, and to design that lacks details important for the contractor. Many of the issues within these categories appear in the very beginning of the project, and can be mitigated (partially or fully) by the owner; while their costs are far away from being excessive.

\section{Discussion and Conclusions}

Delays are a part of the construction projects. In this paper, we wanted to identify the current state in this field within the Slovenian construction industry by carrying out a survey among various construction project stakeholders. Results show that delays are a part of the daily routine during construction project execution. It can be concluded that more attention should be paid to the processes that are taking place prior to construction, such as producing adequate design drawings and documents.

The results of the presented research identify the needs of the construction industry from the viewpoint of time management and delays that occur in projects, and could be used as the baseline for the preparation of guidelines for time management for all construction stakeholders. 


\section{References}

1. González, P., González, V., Molenaar, K., \& Orozco, F. (2014), Analysis of Causes of Delay and Time Performance in Construction Projects, Journal of Construction Engineering and Management, Vol.14O(1), 04013027

2. Majid, M. Z. A., \& McCaffer, R. (1998), Factors of Non-Excusable Delays That Influence Contractors' Performance, Journal of Management in Engineering, Vol.14(3), p.42-49.

3. AlSehaimi, A., Tzortzopoulos, P. \& Koskela, L. (2013), Improving construction management practice with the Last Planner System: a case study, Engineering, Construction and Architectural Management, Vol.21(1), p. 51-64.

4. Faridi, A. S., \& EluSayegh, S. M. (2006), Significant factors causing delay in the UAE construction industry, Construction Management and Economics, Vol.24(11), p.1167-1176.

5. Sweis, G., Sweis, R., Abu Hammad, A. \& Shboul, A. (2008), Delays in construction projects: The case of Jordan, Int.J. of Project Man., Vol 26(6), p.665-674.

6. Yang, Y.-B., \& Kao, C.-K. (2009), Review of Delay Analysis Methods: A Process-Based Comparison, Open Construction \& Building Technology Journal, Vol.3. Retrieved from: http://connection.ebscohost.com/c/articles/51409426/review-delay-analysis-methods-process-based-comparison (Nov.15, 2015)

7. Sun, M., \& Meng, X. (2009), Taxonomy for change causes and effects in construction projects. International Journal of Project Management, Vol.27(6), p.560-572.

8. Kartam, S. (1999), Generic methodology for analyzing delay claims, Journal of Construction Engineering Management, Vol.125(6), p.409-419.
9. Yang, J.B., Chu, M.Y. \& Huang, K.M. (2013), An Empirical study of schedule delay causes based on Taiwan's litigation cases, Project Management Journal, Vol.44, p.21-3.

10. Mahamid, I., Al-Ghonamy, A., \& Aichouni, M. (2015), Risk matrix for delay causes in construction projects in Saudi Arabia, Research J. of Applied Sciences, Engineering and Technology, Vol. 9(8), p. 665-670.

11. Pourrostam, T., \& Ismail, A. (2011), Study of Methods for Minimizing Construction Delays: Evidences from a Developing Country, Advanced Materials Research, Vols. 201-2013, p. 2939-2942.

12. AACE-International. (2011). Forensic schedule analysis - Recommended Practice No. 29R-03. 13. Saggaf, H. A. (1998), The Five Commandments of Construction Project Delay Analysis, Cost Engineering, Vol.40(4), pp.37-41.

14. Kumaraswamy, M.M., \& Chan, D. W. M. (1998), Contributors to construction delays, Construction Management and Economics, Vol.16(1), p.17-29 